\title{
Influence of ageing processes on the structure and physical properties of amorphous-crystalline films of Gd-Fe system
}

\author{
V.Prysyazhnyuk, O.Mykolaychuk \\ I.Franko National University of Lviv, Chair of Physics of Metals, \\ 1 Universytetska Str., 79000 Lviv, Ukraine
}

Received July 20, 2012

\begin{abstract}
Structural and electrophysical studies of thin amorphous and polycrystalline films of Gd-Fe system just after evaporation as well as after 3 years ageing were carried out. The high time stability of these materials has been established.
\end{abstract}

Проведены структурные и электрофизические исследования тонких аморфных и поликристаллических пленок системы Gd-Fe сразу после их получения и через 3 года. Обнаружено высокую временную стойкость данных материалов.

\section{Introduction}

Thin layers of intermetallic compounds of a rare-earth element - iron type are interesting for researchers due to their magnetic properties. These properties are influenced strongly by structural features of these compounds. For example, in $\mathrm{Gd}-\mathrm{Fe}$ system there are many structural types which were studied recently $[1,2]$. It is necessary to note also that methods and conditions of evaporation of the films influence significantly on formation of the structure [3].

\section{Experimental technique}

Thin films of binary compounds of Gd-Fe system were obtained by means of a thermal vacuum evaporation of polycrystalline mix material of a corresponding composition.

The films with thickness of $50-60 \mathrm{~nm}$ were evaporated on splitting of $\mathrm{NaCl}$, and then $\mathrm{NaCl}$ was dissolved in water. The part of the films was picked up at once on copper electron diffraction grids. The second series of the films was transplanted on copper grids preliminarily coated by thin collodion films and in such way was maintained during 3 years. Then recurring researches were carried out. For electrophysical measurements the films were condensed on glassceramics substrates. A thickness of the films changed within 100-200 $\mathrm{nm}$. The films thickness was measured by means of an optical interferometer MIO-1. The temperature of the substrates had two values 300 and $500 \mathrm{~K}$. For structural investigations an electron microscope UEMV-100K and high-temperature attachment PRON-2 were used. Electron diffraction patterns were scanned photometrically using a microphotometer MF-4. Angle dependence of atomic factors of electron scattering on atoms of gadolinium and iron was considered. Specific resistance measurements in vacuum were carried out in special cryostat on the basis of VUP-5 unit. All measurements were repeated in 3 years after the first stage of the investigation.

\section{Discussion}

Structural investigations of $\mathrm{GdFe}_{2}$ films have been already performed by us [1,2]. It has been revealed that $\mathrm{GdFe}_{2}$ films condense in structural type $\mathrm{MgCu}_{2}$ (face-centered cubic lattice) which is characteristic for the massive samples. In Table 1 the intensity of 
Table 1. Intensities of diffraction peaks and values $d_{n}$ for $\mathrm{GdFe}_{2}$ films which has been evaporated at $T_{s}=500 \mathrm{~K}$ before and after a three-year ageing

\begin{tabular}{|c|c|c|c|c|c|c|c|c|}
\hline \multicolumn{3}{|c|}{$\mathrm{GdFe}_{2}$ film } & \multicolumn{3}{|c|}{$\mathrm{GdFe}_{2}$ film (recurring research) } & \multicolumn{3}{|c|}{ Bulk sample } \\
\hline$I$, r.u. & $d_{n}, \mathrm{~nm}$ & (hkl) & $I$, r.u. & $d_{h k l}, \mathrm{~nm}$ & (hkl) & I, r.u. & $d_{n}, \mathrm{~nm}$ & (hkl) \\
\hline 63 & 0.266 & $(022)$ & 63 & 0.266 & $(022)$ & 63 & 0.261 & $(022)$ \\
\hline 100 & 0.217 & $(113)$ & 100 & 0.217 & $(113)$ & 100 & 0.223 & $(113)$ \\
\hline 12 & 0.186 & $(222)$ & 13 & 0.186 & $(222)$ & 16 & 0.213 & $(222)$ \\
\hline 12 & 0.164 & $(224)$ & 13 & 0.164 & $(224)$ & 3 & 0.170 & $(133)$ \\
\hline 10 & 0.145 & $(333)$ & 10 & 0.145 & $(333)$ & 20 & 0.151 & $(224)$ \\
\hline \multirow[t]{4}{*}{11} & 0.132 & $(044)$ & 10 & 0.132 & $(044)$ & 19 & 0.142 & (333) \\
\hline & & & & & & 18 & 0.131 & $(044)$ \\
\hline & & & & & & 7 & 0.117 & (026) \\
\hline & & & & & & 7 & 0.113 & (335) \\
\hline \multicolumn{3}{|c|}{$a=0.750 \mathrm{~nm}$} & \multicolumn{3}{|c|}{$a=0.750 \mathrm{~nm}$} & \multicolumn{3}{|c|}{$a=0.740 \mathrm{~nm}$} \\
\hline
\end{tabular}

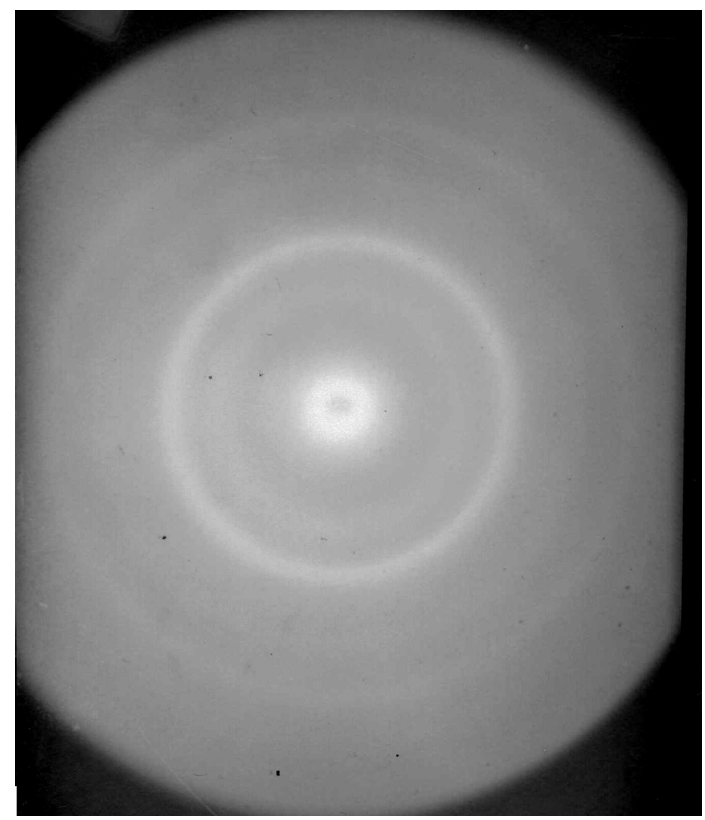

Fig. 1. Electron diffraction patterns of amorphous $\mathrm{Gd}_{2} \mathrm{Fe}_{17}$ film $\left(T_{\text {substrate }}=300 \mathrm{~K}\right)$.

diffraction peaks and value of $d_{h k l}$ for amorphous-crystalline films $\mathrm{GdFe}_{2}$ condensed at $T_{s}=500 \mathrm{~K}$ as-obtained and aged during 3 years as well as for massive $\mathrm{GdFe}_{2}$ are listed. No any structural changes are observed. Especially it is necessary to note the lack of processes of an oxidizing.

In Fig. 1, 2 it is shown the electron diffraction patterns of $\mathrm{Gd}_{2} \mathrm{Fe}_{17}$ compounds at the different substrate temperatures. In Fig. 3 the photomicrography of amorphouscrystalline $\mathrm{Gd}_{2} \mathrm{Fe}_{17}$ film is preserved. Under identification of structure of the films for $\mathrm{Gd}_{2} \mathrm{Fe}_{17}$ compounds it is necessary to consider that this compound crystallizes in two

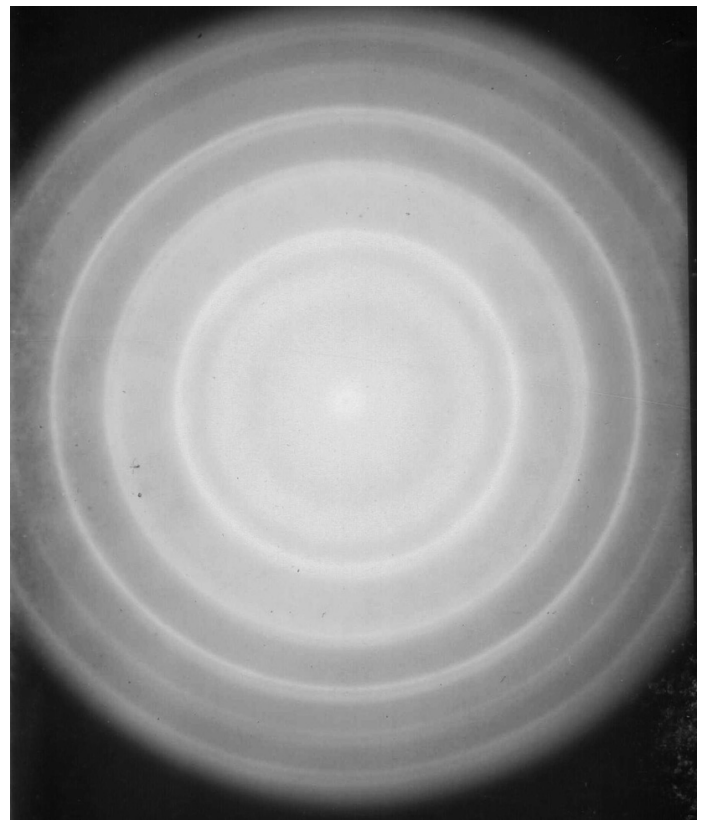

Fig. 2. Electron diffraction patterns of amorphous-crystal $\mathrm{Gd}_{2} \mathrm{Fe}_{17}$ film $\left(T_{\text {substrate }}=500 \mathrm{~K}\right)$.

structural types [4]. $\mathrm{Gd}_{2} \mathrm{Fe}_{17}$ films which were condensed at temperature of a substrate $T_{s}=500 \mathrm{~K}$ consisted of an intermixture of three compounds - hexagonal $\mathrm{Gd}_{2} \mathrm{Fe}_{17}$ with structural type $\mathrm{Th}_{2} \mathrm{Ni}_{17}$, rhombohedral $\mathrm{Gd}_{2} \mathrm{Fe}_{17}$ with structural type $\mathrm{Th}_{2} \mathrm{Ni}_{17}$ and hexagonal $\mathrm{GdFe}_{5}$ with structural type $\mathrm{CaCu}_{5}$ (Table 2). In Table 2 also are shown the data of intensity of the diffraction peaks, values $d_{n}$ and parameters $S$ ( $S=2 \pi / d_{n}, \mathrm{~nm}^{-1}$ ) for the films gained at $T_{s}=500 \mathrm{~K}$ as-obtained and after 3 years ageing at room conditions. The positions of the diffraction peaks have not changed. It testifies to the fact that the formed struc- 
Table 2. Intensities of diffraction peaks, values $d_{n}$ and parameters $S\left(S=2 \pi / d_{n}, \mathrm{~nm}^{-1}\right)$ for $\mathrm{Gd}_{2} \mathrm{Fe}_{17}$ films which has been evaporated at $T_{s}=500 \mathrm{~K}$ before and after a three-year ageing

\begin{tabular}{|c|c|c|c|c|c|c|c|c|}
\hline \multicolumn{5}{|c|}{$\mathrm{Gd}_{2} \mathrm{Fe}_{17}$ film } & \multicolumn{4}{|c|}{$\mathrm{Gd}_{2} \mathrm{Fe}_{17}$ film (recurring research) } \\
\hline \multirow{2}{*}{\multicolumn{2}{|c|}{$\begin{array}{c}I, \text { r.u. } \\
70\end{array}$}} & \multirow[t]{2}{*}{$d_{n}, \mathrm{~nm}$} & \multirow{2}{*}{\multicolumn{2}{|c|}{$\begin{array}{c}S, \mathrm{~nm}^{-1} \\
21.1\end{array}$}} & \multirow{2}{*}{$\begin{array}{c}I, \text { r.u. } \\
71\end{array}$} & \multicolumn{2}{|c|}{$d_{n}, \mathrm{~nm}$} & $S, \mathrm{~nm}^{-1}$ \\
\hline & & & & & & 0.2 & & 21.1 \\
\hline \multicolumn{2}{|l|}{55} & 0.245 & \multicolumn{2}{|c|}{25.6} & 55 & 0.245 & & 25.6 \\
\hline \multicolumn{2}{|l|}{100} & 0.211 & \multicolumn{2}{|c|}{29.8} & 100 & \multicolumn{2}{|c|}{0.211} & 29.8 \\
\hline \multicolumn{2}{|l|}{35} & 0.208 & \multicolumn{2}{|c|}{30.2} & 35 & \multicolumn{2}{|c|}{0.208} & 30.2 \\
\hline \multicolumn{2}{|l|}{45} & 0.188 & \multicolumn{2}{|c|}{33.6} & 45 & \multicolumn{2}{|c|}{0.188} & 33.6 \\
\hline \multicolumn{2}{|l|}{40} & 0.148 & \multicolumn{2}{|c|}{42.4} & & 0.1 & & 42.4 \\
\hline 55 & & 33 & 47. & & & 0.1 & & 47.2 \\
\hline 30 & & 22 & 51 . & & & 0.1 & & 51.9 \\
\hline 25 & & 05 & 59. & & & 0.1 & & 59.8 \\
\hline 25 & & 90 & 69. & & & 0.0 & & 69.8 \\
\hline $\begin{array}{c}\text { Bulk } \\
\text { (struct }\end{array}$ & $\begin{array}{l}\text { ample } \mathrm{Gc} \\
\text { ral type }\end{array}$ & $\left.\mathrm{di}_{17}\right)$ & $\begin{array}{r}\mathrm{Bul} \\
\text { (stru }\end{array}$ & $\begin{array}{l}\text { ample } G \\
\text { ral type }\end{array}$ & & $\begin{array}{r}\mathrm{B} \\
\text { (str }\end{array}$ & $\begin{array}{l}\text { sample } \\
\text { tral type }\end{array}$ & $\begin{array}{l}\mathrm{CaCe}_{5} \\
\left.\mathrm{CaCu}_{5}\right)\end{array}$ \\
\hline I, r.u. & $d_{n}, \mathrm{~nm}$ & hkl & I, r.u. & $d_{n}, \mathrm{~nm}$ & hkl & I, r.u. & $d_{n}, \mathrm{~nm}$ & $\mathrm{hkl}$ \\
\hline 30 & 0.298 & 112 & 82 & 0.297 & 113 & 40 & 0.298 & 101 \\
\hline 43 & 0.245 & 030 & 73 & 0.247 & 030 & 26 & 0.245 & 110 \\
\hline 46 & 0.212 & 220 & 26 & 0.238 & 024 & 35 & 0.213 & 200 \\
\hline 100 & 0.211 & 032 & 100 & 0.214 & 220 & 100 & 0.211 & 111 \\
\hline 28 & 0.209 & 004 & 97 & 0.212 & 033 & 30 & 0.208 & 002 \\
\hline 22 & 0.189 & 222 & 53 & 0.207 & 006 & 22 & 0.159 & 112 \\
\hline 35 & 0.187 & 114 & 32 & 0.190 & 223 & 21 & 0.150 & 211 \\
\hline 17 & 0.134 & 332 & 24 & 0.149 & 226 & 30 & 0.149 & 202 \\
\hline 15 & 0.123 & 060 & 27 & 0.135 & 333 & 34 & 0.134 & 301 \\
\hline & & & 23 & 0.123 & 060 & 25 & 0.123 & 220 \\
\hline & & & & & & 26 & 0.121 & 113 \\
\hline & & & & & & 37 & 0.106 & 222 \\
\hline & & & & & & 20 & 0.099 & 303 \\
\hline & & & & & & 45 & 0.091 & 411 \\
\hline
\end{tabular}

tures have not changed with ageing, and also oxidizing process has not been observed. If to compare an intensity of the maxima it is possible to observe an insignificant redistribution of the phase's percentage content. The content of hexagonal $\mathrm{Gd}_{2} \mathrm{Fe}_{17}$ compound with the structural type $\mathrm{Th}_{2} \mathrm{Ni}_{17}$ has decreased $(60 \% \rightarrow 50 \%)$. The content of rhombohedral $\mathrm{Gd}_{2} \mathrm{Fe}_{17}$ compound with the structural type $\mathrm{Th}_{2} \mathrm{Ni}_{17}$ has increased (30\% $\rightarrow 40 \%)$. The only phase which has not changed the percentage content is hexagonal $\mathrm{Gd}_{2} \mathrm{Fe}_{5}$ with the structural type $\mathrm{CaCu}_{5}(10 \%)$.

As a whole, the trend to the further crystallization of amorphous-polycrystalline films is observed. Electron diffraction studies confirm this suggestion (peaks become of the higher resolution).

We also carried out the repeated electrophysical investigations of the films of these compounds. In Table 3 values of a specific

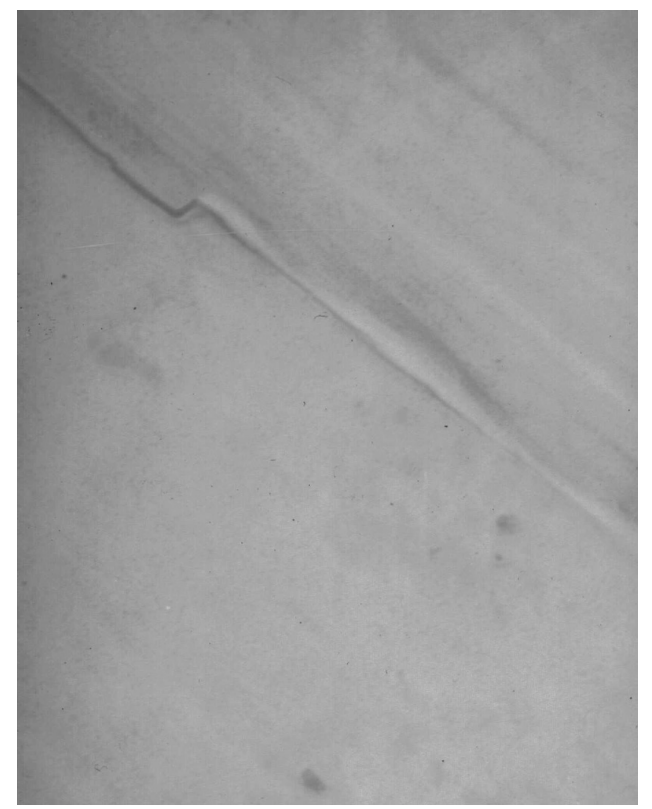

Fig. 3. Microscopic structure of amorphouscrystalline $\mathrm{Gd}_{2} \mathrm{Fe}_{17}$ film $\left(T_{\text {substrate }}=500 \mathrm{~K}\right)$. 
Table 3. Electrophysical properties of the films

\begin{tabular}{|c|c|c|c|}
\hline & $\mathrm{GdFe}_{2}$ & $\mathrm{GdFe}_{5}$ & $\mathrm{Gd}_{2} \mathrm{Fe}_{17}$ \\
\hline \multicolumn{4}{|c|}{ Specific electroresistance $(\mathrm{mkOm} \cdot \mathrm{cm})$ at $T_{\text {measuring }}=300 \mathrm{~K}$ and $T_{\text {substrate }}=300 \mathrm{~K}$} \\
\hline as-obtained & $3.75 \cdot 10^{4}$ & $1.09 \cdot 10^{4}$ & $2.12 \cdot 10^{3}$ \\
\hline after 3 years aging & $3.77 \cdot 10^{4}$ & $1.04 \cdot 10^{4}$ & $2.14 \cdot 10^{3}$ \\
\hline \multicolumn{4}{|c|}{ Specific electroresistance $(\mathrm{mkOm} \cdot \mathrm{cm})$ at $T_{\text {measuring }}=300 \mathrm{~K}$ and $T_{\text {substrate }}=500 \mathrm{~K}$} \\
\hline as-obtained & $5.63 \cdot 10^{4}$ & $4.03 \cdot 10^{4}$ & $9.26 \cdot 10^{3}$ \\
\hline after 3 years aging & $5.60 \cdot 10^{4}$ & $4.08 \cdot 10^{4}$ & $9.31 \cdot 10^{3}$ \\
\hline
\end{tabular}

resistance for $\mathrm{GdFe}_{2}, \mathrm{GdFe}_{5}, \mathrm{Gd}_{2} \mathrm{Fe}_{17}$ films are given at temperature $300 \mathrm{~K}$ (films have been evaporated at the substrate temperature $T_{S}=500 \mathrm{~K}$ ). These effects confirm the fact that mechanisms of charge transfer and the concentration of carrying agents remain invariable.

\section{Conclusion}

The high time stability of physical characteristics of Gd-Fe films and lack of their oxidizing have been revealed. It is known also that these materials belong to a class of magneto-soft materials [4]. This fact uncloses major prospects for using the films of these compounds as magnetization reversal systems in the information magnetic recording systems.

\section{References}

1. V.Prysyazhnyuk, O.Mykolaychuk, J. NonCrystal. Solids, 352, 4299 (2006).

2. V.Prysyazhnyuk, O.Mykolaychuk, J. Non-Crystal. Solids, 354, 4458 (2008).

3. V.Prysyazhnyuk, O.Mykolaychuk, in: Proc. XV Int. Sem. on Physics and Chemistry of Solids, Lviv (2010), p.55.

4. M.Zinkevich, N.Mattern, H.J.Seifert, J. Phase Equilibria, 21, 385 (2000).

\title{
Вплив процесів старіння на структуру та фізичні властивості аморфно-кристалічних плівок системи Gd-Fe
}

\author{
Присяжнюк В.І., Миколайцук О.Г.
}

Проведено структурні та електрофізичні дослідження тонких аморфних та полікристалічних плівок системи Gd-Fe зразу після отримання і через 3 роки. Встановлено високу часову стійкість даних матеріалів. 